IZA DP No. 10100

Deconstructing Informality:

A Response to Vulnerability or an Optimal Choice?

Lina Song

Simon Appleton

Zhe Liang

July 2016 


\title{
Deconstructing Informality: A Response to Vulnerability or an Optimal Choice?
}

\author{
Lina Song \\ University of Nottingham and IZA \\ Simon Appleton \\ University of Nottingham and IZA \\ Zhe Liang \\ University of Nottingham
}

Discussion Paper No. 10100

July 2016

IZA

P.O. Box 7240

53072 Bonn

Germany

Phone: +49-228-3894-0

Fax: +49-228-3894-180

E-mail: iza@iza.org

Any opinions expressed here are those of the author(s) and not those of IZA. Research published in this series may include views on policy, but the institute itself takes no institutional policy positions. The IZA research network is committed to the IZA Guiding Principles of Research Integrity.

The Institute for the Study of Labor (IZA) in Bonn is a local and virtual international research center and a place of communication between science, politics and business. IZA is an independent nonprofit organization supported by Deutsche Post Foundation. The center is associated with the University of Bonn and offers a stimulating research environment through its international network, workshops and conferences, data service, project support, research visits and doctoral program. IZA engages in (i) original and internationally competitive research in all fields of labor economics, (ii) development of policy concepts, and (iii) dissemination of research results and concepts to the interested public.

IZA Discussion Papers often represent preliminary work and are circulated to encourage discussion. Citation of such a paper should account for its provisional character. A revised version may be available directly from the author. 


\section{ABSTRACT \\ Deconstructing Informality: A Response to Vulnerability or an Optimal Choice?}

The rapid growth of informal employment in China in recent decades has attracted attention, but to understand its implications, the concept of informality must be deconstructed. We reclassify employment status into three categories: salaried workers who have long-term contracts; the self-employed; and causal workers without long term contracts (working in either the formal or the informal sector). The monthly earnings of the self-employed are much $(47 \%)$ higher than those casual employees. Self-employment is not necessarily a misfortune and the flexibility it provides may be optimal for some kinds of workers. For example, the selfemployed are more likely to be disabled and to have young families. Institutionally, it is still difficult for casual workers and most rural-urban migrant workers to embark on business ownership. Although a large group of rural-urban migrants are employees with longer term contracts, their rural registration (hukou) means they lack the social protection of urban residents. The labour force with rural hukou is more likely to fall into the informal sector and, within that sector, is most likely to be engaged in casual labouring jobs. Policies to support small businesses may be warranted given the detrimental impacts of informality on casual workers. Experimental interventions could be tried along the lines of those used in Peru to provide funds to support entrepreneurial activities by this group to lift themselves out of a poverty trap into more sustainable employment. Skill training, encouragement for innovation, tax credits and reducing institutional constraints on starting up small business should be all considered.

JEL Classification: J24, J46, J48

Keywords: informality, vulnerability, self-employment, casual labour, China

Corresponding author:

Lina Song

School of Sociology and Social Policy

University of Nottingham

Nottingham, NG7 2RD

United Kingdom

E-mail: Lina.song@nottingham.ac.uk 


\section{Introduction}

Conventionally, the informal sector is regarded as a hub for the poor who need work but could not find formal employment. It is a residual sector, a refugee for the vulnerable. More recently, however, it seems to be attracting the skilled, people with business assets and even risk-takers. For such people, the informal sector may be their first preference: their optimal choice, rather than a second best to formal employment. In China, the trend of informal employment therefore has been to increase rather than enter an expected decline. Among policy makers, there are now both positive and negative views of this trend. Some in Shanghai have openly welcomed the emerging of informal employment; its mayor published an article regarding the informal employment as the 'cradle of a new type of economic organisations' (Chen, 1999). Conversely, others continue to advocate reducing the size of informal sector. The ILO, for example, still expresses the view that informality is the trap for the vulnerable.

The ILO perspective originates from earlier studies of labour markets in developing nations, which characterised them as dualistic. Low-skilled rural-urban migrant workers who left the village but could not secure well paid urban formal jobs would stay in urban areas but survive through low return informal employment. Based on the theoretical assumptions supported by some limited empirical findings, the informal economy was first conceptualised by ILO as an adverse phenomenon for the poor in low income developing countries. Within the informal sector, working conditions were bad, hours worked long, pay low, and little or no social protection provided. Informality was further associated with labour market failures and chronic poverty (ILO, 2016).

Within this negative perspective, informal work would only attract the vulnerable: women, the disabled, low-skilled manual or migrant workers with few opportunities to find formal jobs. It was a residual activity for those unable to obtain more desirable, higher quality jobs in the formal sector. Conceptually, the informal sector was seen as something that emerged when the supply of labour exceeds the demand. It catered to those who had been forced out of the formal labour market by above market-clearing wages and were essentially queuing for scarce formal sector jobs.

However, findings from recent research provide some counter-arguments to the above perspective. There is some evidence that more and more well-off or highly skilled workers are willingly engaged in the so-called informal sector in the more developed economies. Those less competitive may also be learning to be more competitive by gaining experience or accumulating human capital. There is beginning to be a paradigm shift in conceptualising the informal sector in recent decades, partly as a result of trends in individual worker choice. Empirical evidence reveals a trend of voluntary switching from formal salaried jobs to selfemployment in many countries, both developed and developing (see Maloney, 2004, for a comprehensive review).

In advanced economies of the global North, the fast growth of international trade with the South, among other factors, has reduced the scale of their manufacturing sectors and created job losses. Additionally, technological progress has altered the economic weights of various industrial sectors, causing displacement of workers and changing views on 'work'. Consequently, small micro firms and self-employment - what might traditionally been thought to be part of the 'informal sector' - have been are promoted by Western governments as a means of resolving the unemployment arising from the reduction in manufacturing jobs. While unemployment may act as a 'push factor', the potential attractions of self-employment should not be 
overlooked: a large proportion of labour force in the US, UK and Germany report that they preferred to be self-employed (Blanchflower and Oswald, 1998).

In the mid-1990s's Peru, the informal economy was promoted as the way to resolve terrorism. The Shining Path, a Maoist guerrilla organisation, had attracted thousands of landless and other poor people to its cause, leading to violent incidents across the country (De Soto, 2002). In an effort to reduce popular unrest by generating pro-poor growth, de Sato and his team started to work on the development of an effective informal sector for Peru. A key theme was to change 'dead capital' into 'live capital': those engaged in informal economy, either small business owners or those engaged in informal jobs, should helped to gain access to loans by giving them property titles within slums or poor neighbourhoods. The plan was to make homeowners out of poor squatters, eventually formalising a vast extra-legal world by titling and hence giving the poor access to credit. This agenda was embraced by a variety of political figures. They included policy-makers such as American presidents, heads of states in developing countries and international organisations like the World Bank. Left-wingers welcomed his ideas as means to reduce the global poverty, whilst for the right, De Soto 'offers the most compelling way to market capitalism to the poor' (Gravois, 2005).

The Peruvian case of promoting informality can be relevant to China, where private property rights for some are weak or non-existent due to a legacy of state and collective ownership. Although Chinese central government policy-makers eschew the term informality and deny its existence in China, several scholars and local government policy-makers would be in favour of the movement towards informal job creation in China. This paper therefore aims to provide some insights on these concerns.

In this paper, we identify the different elements in the informal sector and examine the determinants of employment status. Our objectives are the following:

1. We provide some understanding of how different elements of 'informal employment' by examining the institutional changes in the Chinese labour market, both rural and urban.

2. We reclassify employment status by characterising the Chinese informal sector and establishing which element of 'the informal sector' is still a hub for the vulnerable.

3. We investigate the determinants of employment status highlighting why some fall into informal employment and establishing the relationship between informality and vulnerability.

The organisation of this paper is as the follows. Section 2 explains the definition of informality and its evolution. Section 3 discusses the Chinese context of informal employment and how it has been constructed and understood. Section 4 provides empirical analysis on the determinants of employment status focusing on informal employment. Section 5 concludes.

\section{Deconstructing informality: definition and its evolution}

Informal employment or employment in the informal sector was first discussed by Lewis (1954) in his dual-sector model. In it, a developing economy is assumed to have a surplus of unproductive labour in its agricultural sector (or subsistence sector), and they are attracted to and migrate to urban sector for the better paid manufacturing jobs (or capital sector). Those who fail to secure jobs in the capital sector would be regarded as in the informal sector. 
Harris and Todaro (1970) further developed this dualistic model by focussing on rural to urban migration. They assumed the formal urban sector has a wage above the market clearing level and it is rigid downwards. Rural to urban migration causes unemployment in the urban sector as there would be more migrant workers than jobs created in urban sectors. Thus less skilled or competitive migrants would end up in unproductive or underproductive employment in the informal sector. However, even though this migration creates unemployment and induces informal sector growth, the behaviour of migrants is economically rational and utilitymaximizing in the context of the Harris-Todaro model. As long as the migrating economic agents have complete and accurate information concerning rural and urban wage rates and probabilities of obtaining employment, they will make an expected income-maximizing decision, as the high formal sector wage compensating for chance of not securing such a wage and remaining in urban informal employment.

The ILO (1993) defined informal employment in terms of business ownership using a productive unit (usually family or among friends) whose fixed assets pertain to the informal sector and belong to the owners. Labour relationships in these units are mainly based on personal and social ties. Given these characteristics, the informal sector is usually associated with small business units within which capital and labour may be difficult to separate and where the level of productivity may be low. Such business units barely survive, rather than accumulate capital for future investment. Further, jobs generated in this sector constitute the employment in the informal sector (EIS), usually referring to those who have little or no fixed assets for the kind of work they do in the informal sector.

The distinction between "informal employment (IE)" and "employment in informal sector (EIS)" discussed above would have different determinants and consequences. Hussmanns (2004) pointed out that "Employment in the informal sector and informal employment refer to different aspects of the 'informalisation' of employment and to different targets for policymaking. The two concepts cannot replace each other. However, the two concepts need to be defined and measured in such a way that they are consistent and that one can be clearly distinguished from the other". Further to Hussmanns, we suggest examining whether those who own fixed assets for their economic activities (IE) are far better off than those without (EIS), and whether the latter would be more likely to become IE than to work in a non-subsistence sector. In simpler terminology, we refer to small business owners (instead of informal employment, IE) and informal sector workers (instead of employment in informal sector, EIS).

\section{Chinese context and issues: the nature of informality and its implications for China}

In the Chinese context, as was suggested above, the concepts of informal employment and employment in the informal sector may not be sufficient to cover all the elements of informality existing in, or emerging from, the current labour market. In particular, neither concept includes the casual workers who are engaged in China's formal sector. This group of workers have either no employment contract or short-term contracts (less than two years), and obtain little or no welfare payments. Including this element in the analysis of the labour market is crucial in order to understand informality in China (it may also need to be addressed in other countries).

Historically, one may argue that there were no or fewer informal jobs available during China's planning period. All the urban labour force then was engaged in the state-owned or collectively managed enterprises. The rural labour force was controlled by the People's Communes since 1958 with very little scope for peasants to leave the farms for urban job, either formal or 
informal (Knight and Song, 1999). However, since the abolishment of collective farming in the early 1980s, agricultural production in China is conducted by a more diverse rural labour force. The great trend of rural-urban migration since the 1990s, coupled with the remaining ambiguous land ownership for the rural population and increased opportunities of non-farm jobs, has left Chinese agriculture in an inefficient mode, not benefiting from economies of scale.

Instead of accepting the term 'informality', the Chinese authorities use the terms 'self-decided employment' (自主就业) and 'self-employment' (自我就业, 自雇) to describe workers who are not in formal employment jobs in urban China. The politics behind such a denial itself is worth exploring. Informality may be seen as contradicting CCP's fundamental principles as a communist regime. Recognising informality would indicate failure in assisting the vulnerable and the limits of government control. Conflicts and social instability may be worsening due to the huge reduction of the state-owned jobs.

Huang (2013) argues that in China, the two main social classes should now be defined by employment sectors - formal and informal. According to him, only small number of 'bluecollar workers' are 'privileged to be included in the formal job sector', protected by the State's social insurance. He fears that the gap between the two sectors leads to 'social-economic crisis confronting China today and cries out for reform'. Informality might be the new touchstone for social class division: the well-recognised rural-urban divide analysed by Knight and Song (1995) may be being supplanted by a formal-informal divide.

All this may haunt the Chinese leadership. Seeking to avoid this divide, the Chinese government has consistently emphasised controlling the speed of rural to urban migration, although in practice these controls have been ineffective. The scale of migration in China has rapidly expanded since the 1990s, with the current official estimate being that 270 million people work away from their registered origins. When the number of their dependents living in cities is added to this, the estimated total number of migrants in China amounts to 500 million (Lu, 2013).

Confronted by the largest population movement historically and across the world, the Chinese regime faces a dilemma between its pursuit for GDP growth and its desire for orderly management of migration. Central policy dossiers since 1990s reveal government flexibility when regarding China's rural-urban migration. However, its denial of informality is consistent and firm. The term of informal employment is not used in official statistics. Self-employed individuals and employed persons in private enterprises are recorded and while these may be taken to reflect the informal employment, the equivalence is partial.

Whether informality should be seen as a cause of concern or merely a substitute for the lack of formal job opportunities is an issue that has been examined by various empirical studies. Zhang and Cai (2012) estimate that labour market participation dropped from $79.0 \%$ in 1990 to $73.4 \%$ in 2009 using national labour statistics. In their article, flexible jobs (or informal employment) are regarded as low quality of employment due to the low income they provide and the lack of social protection for those who are engaged in the sector. They advocate that the Chinese labour market is overly flexible, allowing informal jobs to emerging without social protection whilst the formal sector is overly protective.

Cai (2007) explores how the true size of informal employment may be misreported. He finds that in official labour statistics, self-employed workers in individually owned businesses or small private enterprise are not included in the labour force if they avoid registering their 
business officially. Further, his finding also demonstrates that in the formal sector, including some large state owned enterprises or work units, newly hired or re-employed workers who were made redundant are not included as employees of the firm in officially published statistics. Cai's findings are reflective of the fact that the Chinese government denies the existence of informality, so the full extent of informal sector cannot be measured in official statistics sources. Only after the rapid growth of private sector have scholars started to fully capture the components of employment status via household surveys such as the Chinese Household Income Project surveys (Known as CHIP, 1988, 1995, 2002, 2007 and 2014).

It is unclear whether informal employment is the first preference of those who are engaged in the sector or just a residual hub for those seeking formal jobs, but this can be investigated empirically in various ways. Among those who may prefer being self-employed, a key constraint may be asset ownership, so it is important to disaggregate by this when analysing the sector. To gauge whether the informal sector is merely a residual hub, it is important to determine whether the poor and vulnerable are concentrated within it and, if so, whether there would be ways to lift them out of the sector? We now turn to explain in more detail how informality may exist due to China's particular institutional changes, starting first by considering rural areas and then moving on to urban.

\section{Deconstruct rural informality}

The diversified nature of rural labour force led Huang (2013) to argue that farming should be included in informal sector between 1949 when CCP seized the power and the completion of the People's Commune in 1958; and again after the economic reform since late 1970s when the surplus of rural labour was released and hence has become diverting between farming and non-farming activities.

In the 1990s, when China's rural-urban migration was emerging as 'seasonal' and singleton (not moving with families), diversification of rural labour across various different activities was very common. Such diversification of rural production helped address the issue of surplus farm labour although inefficiencies remained due to key constraints (Song, 2000). If a household has few members to send out as migrants to other region, it may be optimal for them to keep their working members employed locally, in farming and local non-farm work (Knight and Song, 2003).

Using a nationally representative survey recalling 20 year labour market histories (1981-2000), Mohapatra et al (2007) find evidence of an increase in rural labour engaged in non-agricultural self-employment (e.g. local trading, transport and enterprises). The increase is higher in one of China's most prosperous provinces - Zhejiang, which has been regarded as the future of China's rural economy. As in many other developing countries, self-employment in rural China shares many features of a formal small business sector - high productivity and a high stock of human capital. These findings echo Knight and Song's research that a diversified rural labour force would benefit local development and promote entrepreneurship. This view defies the conventional conception of informality that it was only relevant to migrants who have already arrived in the urban sector but could not obtain formal jobs (Lewis, 1954; Harris and Todaro, 1970).

Capital investment to facilitate self-employment, in particular to finance entrepreneurship, is a key issue. Migration remittances (savings from migration sent to the rural sector) or income generated from local non-farm work are important for those saving in order to invest in private 
businesses. Knight and Song (2003) find that estimated returns to labour off farm greatly exceed those on farm work. They also find that having those out-migrants is important for China's rural development as the remittances from migration support not only farming but local development in terms of private housing and, relating to this paper, generating savings for business investment. This is to say, those who have expectations to become small business owners (as the part of informal employment) would have to accumulate capital over time and sacrifice their current level of consumption. This may make them fall into a vulnerable social group, uncovered by social insurance (Song and Appleton, 2008) and may become poor voluntarily, i.e., measured by consumption (Li and Knight, 2006).

Due to the ambiguous land rights - currently on leasehold with collective ownership - the rural labour force tends to flow between farming work and low-skilled non-farming activities. The accumulation of capital to establish businesses is based on individuals' efforts in order to generate savings, but not based on a matching of human capital (skills or capability). As a result, a cohort of the 'rural' labour force has been created who work casually on both farm and nonfarm work, as they intend to keep farming in the expectation of perhaps gaining in the future from their land entitlement. A current trial programme in part of China to promote the sale of leaseholds of rural land has met bottlenecks. This is largely because of the undetermined length of lease, variation of land prices by location and the expectation of much higher prices in the futures. Finding willing buyers is also difficult as the conditions of purchasing land leaseholds are unclear.

Three policy related questions can be addressed in here. First, self-employment (or employment in the informal sector) may be efficient in the utilisation of labour by reducing the number of labourers hoarding within the subsistence sector (farming). Second, due to China's restricted access to resources, rural labourers cannot raise capital by selling rural assets to start businesses nor borrow loans from the banks. This has resulted in compulsory savings which would cause a voluntary vulnerable group. Finally, issues related to informal sector are not just for urban China due to the uncut tie between land and farm leasehold owners. And this group has always been counted as the labour force in farming - their non-farm jobs locally or outside are not be secured with social insurance or contracts.

\section{Explaining urban informality}

Large scale rural to urban migration began in China in the early 1990s when the reform allowed the establishment of a private sector and controls on migration were lessened. Coupled with mass redundancy in the urban state sector in the second half of the 1990s, this caused urban unemployment to soar. By the end of 1999, official figures (possibly under-estimated) put the unemployment rate at $13 \%$ of the Chinese urban labour force with $21 \%$ 'staff and workers' at risk (Appleton, et al, 2002). Informal employment in the Chinese urban sector therefore was a product of policy changes including the radical state sector reforms. The issues relating to informality that have conventionally been discussed in the context of other dualistic and developing economies began to become relevant to China.

Self-employment sector in urban China started to become significant in scale after the late 1970's reforms and has become a mechanism to absorb laid-off workers and the unemployed since the mid-1990s. During the same period, a huge expansion of export-oriented manufacturing along the coastal regions attracted a great number of rural-urban migrants. However, we find that urban laid-workers and rural-urban migrants typically did not appear to 
be competing for the similar jobs (Appleton et al, 2004). Rural-urban migrant were mostly scattered in the informal commercial or service jobs, running private business or did casual work across various industrial sectors. Jobs in the formal sector were mainly for those engaged in the state-owned or public sector, or in foreign directly invested or joint ventures. Due to the institutional restrictions set by the Chinese authorities, no rural-urban migrants without university qualifications would be offered formal jobs. Since 2008 when the New Labour Contract Law was issued, all employers in the formal sector are requested by law to sign contracts with those who had worked for them for two years. It is since then, ambiguity of defining formal or informal employment disappears. The contract provides employees with social security payments while those who are self-employed or causal workers lack this protection.

While it can be difficult to determine precisely which elements in the labour market should be categorised as informal sector, however, it is clear that the state-owned is purely formal. Using national representative labour force surveys, Xia et al (2014) examine the wage gap by the formal sector (state-owned) and put all the rest together. In their work, although urban wage inequality was raised sharply between 1988 and 2007 (the 90/10 wage ratio increased from 2.82 in 1988 to 6.43 in 2007), wage gaps within the non-state sector (informal sector) are larger than within the formal sector (state or public sectors. It was further established that the large wage gap in the non-state sector is mostly from the low wage earners who lack social protection. Examining life satisfaction index, we find that private entrepreneurs, individual business people and those who are typically identified as those in the informal sector have shared the similar level of life satisfaction with those who managed the public sectors (Song and Appleton, 2008).

The existing econometric evidence discussed above raises the question of whether the conventional concepts used to define employment status (by ownership or occupation) are sufficient in examining China's labour market. There is no evidence that, within the informal sector, those who are registered as self-employed and the ones who work casually across the type of employment share the same level of well-being. Consequently, it is likely that the two groups of workers should be distinguished and studied separately as they are not in the same social class. In the next part of the paper, we develop this point.

\section{Defining and explaining the key concepts for the analysis}

Chinese official statistics relating to employment status are not defined to a way that allows full investigation of informal employment. According to the Chinese Statistical Yearbooks of various years, the employed are clearly defined as "persons who are engaged in social working and receive remuneration payment or earn business income, including total staff and workers, re-employed retires, employers of private enterprises, self-employed workers, employers of private enterprises, and individual economy, employees in township enterprises and employed person in rural areas and other employed persons (including teachers in the schools run by the local people, people engaged in religious profession and the servicemen, etc.)". The difficulty comes when defining informal employment or employment in the informal sector. By official definition, 'self-employment' means 'employed persons in private enterprises and self-employed individuals'. Official categories only allow us to distinguish between employed persons in urban private enterprise and self-employed individuals but not to identify those who are in the informal jobs within the formal sector. This latter group is particularly important in 
China given the dominant role of the state-sector. It is therefore problematic to use official statistics to study informal employment.

Not all employed persons engaged in the formal sector are formally employed in China. For example, most the large enterprises, whether state-owned, privately owned or of mixed ownership (joint ventures, listed forms, etc.), hire temporary employees for short-term goals; or hire manual low skilled labourers to do low skilled jobs (cleaners, security guards, nursing assistants, etc.). Employers do not provide such workers with formal contracts, and hence avoid the cost of social protection. Some agents in the formal sector may directly employ casual workers, low or high skilled, to reduce the cost of labour. Alternatively, casual workers in the formal sector may sometimes be employed by a sub-contracted company not by the organisation itself. For example, some security companies would have contract with an organisation (a client); the security company hires and manages the security guards who have no direct employment relations with the organisation.

The contribution of this research is to re-categorise informality by grouping together all those who work temporarily or casually, with no or short-term contracts, regardless of whether they work for a formal and informal employer. Doing so will allow us to distinguish different elements within the officially defined 'self-employment' and to explore whether they have acquired such status due to vulnerability or preference.

In order to empirically deconstruct informality (or informal employment) and make it fit into the rapidly changed Chinese contexts, we start our analysis with an examination of employment status using a nationally representative urban labour force survey (CHIP, 2009). This survey allows us to ignore the officially collected labour statistics, and define informal employment more accurately. The survey separately sampled residents with urban hukou (the 'urban sample') and rural-urban migrants.

Table 1 shows that the distribution of China's urban and rural-urban labour forces by employment status. 'Salaried workers' in the urban sample are the only category in the survey we regard as being in 'the formal sector'. They draw annual salaries, are covered by social insurance and have either permanent or long-term contracts ${ }^{1}$. A second category is the 'selfemployed'. Although we use the same term as official classifications, the self-employed here refers to those who are entrepreneurs of small firms, individual business households and selfemployed with registered status. Our third category which forms a part of the informal employment is 'casual workers'. To study casual workers as our third category is crucial for the analysis of informality. This group is observed very mobile, moving from one employer to the other, or they move from one type of jobs to another. They are more likely to be at the lowest status among urban residents in the labour market, and hence the most vulnerable.

\section{[Table 1 should be here]}

Among rural-urban migrants, we consider three categories: employees (with contracts of two years or more); business owners (self-employed); and casual workers without long-term contracts. $71 \%$ of rural-urban migrants are employees. We are not able to determine whether their employers are in the formal sector or not. However, the data does show which industrial sectors migrant workers are engaged in; some sectors such as commercial, catering,

\footnotetext{
${ }^{1}$ Institutional constraints set for recruiting formal sector employees would have already excluded almost all rural-urban migrant workers unless they have obtained qualifications of university degree level or above.
} 
construction are less likely to be owned by the state. Of all 7049 migrant workers, $51 \%$ are engaged in merchandise and catering sectors. Among the 5029 migrant employees, 39\% are in commercial and catering, $26 \%$ are in manufacturing, $12 \%$ in public service and $10 \%$ in construction (Table 2 refers). This supports the common observation that most rural-urban migrant workers are still mostly engaged in China’s urban informal sector.

[Table 2 should be here]

The self-employed and salaried workers earn similar monthly income (the difference is only $2 \%$ ) but both earn $80 \%$ or more than casual workers. Differences in monthly income partly reflect differences in hours worked, so it is also informative to look at income per hour. Here, the salaried workers are favoured, earning a third more than the self-employed and nearly double the hourly rate of casual workers.

While a labour law of 1995 states that employers should not allocate more than 8 hours per day or 44 hours per week maximum to their employees, it is clear from Table 3 that this is binding for salaried workers but not the informal sector. Salaried workers actually work two hours less than the national maximum whilst the casual workers on average just work one hour more than that the law- permits. However, the weekly hours for the self-employed group is 13 hours above what the law permits.

\section{[Table 3 should be here]}

In further analysis of this data, not repeated here for brevity, Liang (2015) tabulates the distribution of employment by income quartile. Migrant workers in casual work have the lowest levels of income: $52 \%$ are concentrated in the bottom income quartile compared to 33\% and $26 \%$ of migrant employees and migrant business owners respectively. Conversely, urban salaried workers, business owners, and self-employed workers are concentrated in the top income quartile (43\%, 37\% and 35\% respectively). These results above are largely expected as rural-urban migrants cannot be given jobs in the formal sector due to the long-standing policies against them. It is not appropriate to assume that there are equal opportunities between the rural and urban labour forces in the labour market competition, although the gap in terms of wage rate may be gradually narrowed (Appleton, 2005). Discrimination against rural-urban migrants or rural residents will continue to last although gradual changes towards a more competitive labour market may take place.

Focussing on the urban labour force survey, Table 4 presents statistics on education, age and gender across the three types of workers. Human capital may play a key role in assisting workers to improve their employment status. Urban salaried employees on average have two more years of education than both self-employed and casual workers. Gender and age are important for identifying vulnerabilities. Discrimination against the older or female workers may prevent entry to the formal sector. Indeed, the informal sector might be regarded as a hub for those who have difficulty in gaining access to formal employment. There are no marked differences in mean age among all three categories, although casual workers one year older than the other two groups. More women are engaged in casual work (52\%) than selfemployment (50\%) and salaried workers (48\%).

[Table 4 should be here] 
Another indicator of vulnerability within a human capital framework is the health related physical ability of a labour-force which is documented in Table 5. From the surveys, three types of variables are used for this purpose - self-reported health status, disability and anthropometric status (height and weight). In comparison with the other two groups, salaried workers are slightly healthier - $69 \%$ of salaried work group, $67 \%$ of self-employed and $63 \%$ of casual work report being very healthy or healthy. Salaried workers are over one centimetre taller than the other two groups; and have the lowest disability rate. In terms of height and weight, casual workers are the worst off. It is worth noting that for the self-employed, four of 100 people are disabled - this is doubled that of the salaried group and one disabled person more than in the casual labour group. The self-employed also have the highest proportion that is reported not healthy or very unhealthy. These findings suggest the informal sector may sometimes cater to whose physical limitations limit their competitiveness in the formal labour market.

\section{[Table 5 should be here]}

Family demographic structure is another dimension to consider when appraising the role of vulnerability in labour market competition. If a household has young children to care for, selfemployment would provide flexibility and freedom in handling between jobs and care. Table 6 classifies workers into four according to their relation to the household head. Spouses of household heads are more likely to be engaged in self-employed work, while adult children are less likely. The self-employed also live in larger households with more children and siblings. Although the descriptive statistics do not establish causality, they suggest that the informal sector may be more attractive for those with a large family and more children to care for. In addition, 91 percent of the self-employed are married while only $79 \%$ of casual workers actually are. The latter has the highest proportion of divorcees $-3.24 \%$ against $0.72 \%$ for business owners and $1.9 \%$ for salaried employees.

\section{[Table 6 should be here]}

\section{Determinants of employment status}

In identifying the key determinants affecting whether an individual works in the informal sector, we focus on three sets of variables: those proxying institutional factors, vulnerability and those only relevant if informality was optimal for the worker. One hypothesis is being in the lowest employment status - causal work - may be due to institutional constraints. A second hypothesis is being engaged in the informal business sector may be optimal in terms of 'convenience'. That is to say, it may be optimal given the condition of 'vulnerability', providing the vulnerable people the most suitable way to overcome their difficulties and enhance their livelihoods. We do this by estimating a multinomial logit model of employment status over a pooled survey of both urban and migrant labour force (for brevity this paper does not report the tables related to the discussion, but these information are available in Appleton and Song, 2015).

We examine the institutional variables separating China's urban residents and migrant labour forces, the most obvious indicator of a division is the formal residentship registration (hukou). No matter how long an average rural-urban migrant has worked in the urban sector, this person will not be granted urban hukou. Therefore using the hukou of one's origin may capture the role of this institutional constraint on labour. In the model of employment status estimated over 
the pooled data of all workers, we find that hukou status does indeed significantly affect type of employment. Those with urban resident registration are more likely to be business owners, or employees (salaried for urban workers, or with longer term contract for migrant workers). To become self-employed labourers including those who word casually with no contracts, the likelihood is much lower for urban hukou holders. The probabilities estimated show that urban hukou holders are $6 \%$ more likely to be employees, $9 \%$ to be business owners than their rural counterparts. On the contrary, urban hukou holders are 15\% less likely to be self-employed casual workers than their rural counterparts (i.e., migrant workers). Other variables which may pick up some effects of institutional defaults may be the set of industrial sector dummies. As explained earlier in this paper, the self-employed are most likely to be in the traditional sectors including catering, commercial or services while employees are likely engaged in the modern formal sectors (real estate, finance or IT).

Vulnerability in this research is proxied by physical ability, i.e. whether an individual is being disabled and, self-reported health status. Either being disabled or in poor health can reduce a worker's competitiveness in the labour market. If we assume that formal employment is selective and only those who have high level of human capital stock would be engaged in it, then those who are vulnerable would be more likely to stay in the informal sector. From our model, we find that being in very poor health and/or disabled are both factors that increase the likelihood of being in self-employment.

To look at the optimality of being in informal employment, we look at the impact of the household having children. We find that those who have children would more likely to work as self-employed relative to working as salaried workers but less likely to work as casual labourers. Self-employment can be regarded as a self-determined engagement as it can provide flexible hours of work, allowing workers to care for children. However, this is not true for casual workers (also defined by us as being in the informal sector). We also find from our multivariate regression analysis that, singletons (the never married, divorced or widowed) are much more likely to work casually than to be salaried workers and business owners.

Another indicator of whether employment status is regarded as optimal by workers is to whether they would like to find another job to replace their current one. This may through light on whether formal employment is regarded as the ideal by most workers or whether the selfemployed are content with their employment status. Do casual workers accepting their seemingly low employment status with no social protection, no contract and low income? When we model whether workers would like to find an alternative, we find the relative risk ratio for self-employed (including small business owners) is only slight (0.14) higher for than salaried workers whilst that for casual workers is much higher (2.85). This shows that in comparison with employees in the formal sector, casual labourers are far more likely to seek for another job than their self-employed counterparts. 


\section{Concluding remarks and policy implications}

In this paper, we classify employment status into three categories: salaried workers who have long-term contracts; self-employed; and causal workers without long term contracts (working in either the formal or the informal sector). When examining the differences between selfemployed business owners and casual workers, we find they share similar levels of educational attainment. When turning to the measures of vulnerability, we find that business owners are less healthy and more are classified as being disabled although slightly taller and heavier in weight. Yet, the monthly earnings of the self-employed are much (47\%) higher than casual workers. We therefore believe being self-employed is not necessarily a misfortune and may be optimal for some kinds of workers. In particular, we explored further and discovered that the two kinds of informal sector workers share few similarity in terms of family demographic characteristics. The self-employed have younger families and fewer adult working members than casual workers, perhaps because it self-employment allows for more flexible working. Thus even for those who may have physical vulnerability, running their own business may provide an optimal solution to alleviate their disadvantages.

Institutionally, it is still difficult for casual workers and most rural-urban migrant workers to embark on business ownership. Rural hukou origin is still a fundamental constraint to competing freely in the urban Chinese labour market. Although a large group of rural-urban migrants are employees with longer term contracts, their rural hukous means they are still be different from their urban counterparts, having less social protection. It also reflects the choice of employment status as we have discovered, the labour force with rural hukou is more likely to fall into the informal sector and within that sector those with rural hukou are most likely to be engaged in casual labouring jobs.

From the findings discussed above, we would like to suggest several policy implications. First, the detrimental impacts of informality on casual workers should be recognised. This would assist the policy-making to be more effectively deal with this unprotected part of the labour force and more efficiently use the financial means to resolve the issues of potential instability or chronological poverty. Experimental interventions could be tried along the lines of those used in Peru to provide funds to support entrepreneurial activities by this group to lift themselves out of a poverty trap into a more sustainable employment. Second, policies towards small businesses should be made more favourable. Although the government has already decided to simplify the procedure in business registration, more should be done. Skill training, encouragement for innovation, tax credits and reducing institutional constraints on starting up small business should be all considered. 
Table 1 Sample distribution by employment status

\begin{tabular}{|l|l|l|l|l|}
\hline Urban Sample & Total & Salaried worker & Self-employed & Casual worker \\
\hline Number & 6981 & 5268 & 558 & 1155 \\
\hline$\%$ & 100.00 & 75.46 & 7.99 & 16.54 \\
\hline $\begin{array}{l}\text { Rural-urban } \\
\text { migrant sample }\end{array}$ & & $\begin{array}{l}\text { Migrant } \\
\text { employee }\end{array}$ & $\begin{array}{l}\text { Owner (self- } \\
\text { employed) }\end{array}$ & Casual worker \\
\hline Number & 7049 & 5029 & 446 & 1574 \\
\hline$\%$ & 100.00 & 71.34 & 6.33 & 22.33 \\
\hline
\end{tabular}

Source: 2009 CHIP Urban and Migrant Surveys authors' calculation

Note: Causal workers do not have long term job contracts (of 2 years or more) 
Table 2

Distribution of employment status by industrial sector: Rural-urban migrant survey

Unite: number and percentage

\begin{tabular}{|l|l|l|l|l|}
\hline Industry & Total & $\begin{array}{l}\text { Migrant } \\
\text { employee }\end{array}$ & $\begin{array}{l}\text { Owners (self- } \\
\text { employed) }\end{array}$ & Casual worker \\
\hline More traditional industrial sectors: & 1959 & 318 & 1300 \\
\hline $\begin{array}{l}\text { Commercial and } \\
\text { catering }\end{array}$ & $3577(50.74 \%)$ & 190 & 63 \\
\hline Manufacture & $1376(19.50 \%)$ & 1290 & 23 & 40 \\
\hline Construction & $564(8.00 \%)$ & 500 & 24 & 0 \\
\hline More advanced industrial sectors: & $329(4.66 \%)$ & 328 & 1 & 141 \\
\hline Real estate & $778(11.03 \%)$ & 582 & 55 & 24 \\
\hline Public service & $257(3.64 \%)$ & 210 & 23 & 6 \\
\hline $\begin{array}{l}\text { Information and } \\
\text { transportation }\end{array}$ & $168(2.38 \%)$ & 160 & 2 & 1574 \\
\hline Other & 7049 & 446 & \\
\hline $\begin{array}{l}\text { Number of } \\
\text { observations }\end{array}$ & 5029 & & \\
\hline
\end{tabular}

Source: 2009 CHIP Migrant Surveys

Authors' calculation 
Table 3 Income and hours worked by employment status: urban sample

\begin{tabular}{|l|l|l|l|l|}
\hline Variable & Total sample & $\begin{array}{l}\text { Salaried } \\
\text { work }\end{array}$ & $\begin{array}{l}\text { Self- } \\
\text { employed }\end{array}$ & Casual work \\
\hline Monthly income & 2458 & 2651 & 2713 & 1452 \\
\hline $\begin{array}{l}\text { Hours worked per week of } \\
\text { the month income earned }\end{array}$ & 44 & 42 & 57 & 45 \\
\hline Hourly income in Yuan & 14 & 15.8 & 11.9 & 8.1 \\
\hline
\end{tabular}

Source: 2009 CHIP Urban Sample

Authors' calculation 
Table 4

Age, gender and marital status by employment status: urban sample

\begin{tabular}{|l|l|l|l|l|}
\hline Variable & Total sample & $\begin{array}{l}\text { Salaried } \\
\text { work }\end{array}$ & $\begin{array}{l}\text { Self- } \\
\text { employed }\end{array}$ & Casual work \\
\hline Age & 42.1 & 41.9 & 41.6 & 42.3 \\
\hline Female/male \% & 49 & 48 & 50 & 52 \\
\hline Education (in year) & 11.8 & 12.3 & 10.3 & 10.5 \\
\hline
\end{tabular}

Source: 2009 CHIP

Authors' calculation

Table 5 Health and disability by employment status: urban sample

\begin{tabular}{|l|l|l|l|l|}
\hline & Total & $\begin{array}{l}\text { Salaried } \\
\text { worker }\end{array}$ & Self-employed & $\begin{array}{l}\text { Casual } \\
\text { worker }\end{array}$ \\
\hline Heath status: & & & & \\
\hline Very healthy & 12.98 & 13.04 & 13.46 & 12.08 \\
\hline Healthy & 54.90 & 55.86 & 53.32 & 51.31 \\
\hline Generally fine & 29.51 & 28.63 & 29.08 & 33.71 \\
\hline Not very healthy & 2.16 & 2.05 & 2.33 & 2.54 \\
\hline Very poor health & 0.46 & 0.40 & 1.62 & 0.35 \\
\hline Disabled & 2.11 & 1.74 & 3.95 & 2.89 \\
\hline Height $(\mathrm{cm})$ & 166.0 & 166.4 & 165.3 & 164.8 \\
\hline Weight $(\mathrm{kg})$ & 62.7 & 62.9 & 62.9 & 61.7 \\
\hline
\end{tabular}

Source: 2009 CHIP

Authors' calculation 
Table 6 family structure by employment status

\begin{tabular}{|l|l|l|l|l|}
\hline & Total & Salaried work & Self-employed & Casual work \\
\hline Household head & 40.34 & 40.64 & 39.96 & 39.13 \\
\hline Spouse & 36.06 & 35.29 & 43.73 & 35.84 \\
\hline $\begin{array}{l}\text { Adult children (inc in- } \\
\text { laws) }\end{array}$ & 21.67 & 22.33 & 13.80 & 22.94 \\
\hline Parents (incl in-laws) & 1.93 & 1.74 & 2.51 & 2.09 \\
\hline Number of siblings & 3.19 & 3.09 & 3.56 & 3.48 \\
\hline Number of HH members & 3.26 & 3.24 & 3.37 & 3.29 \\
\hline $\begin{array}{l}\text { Family members aged } \\
0-6\end{array}$ & 0.155 & 0.152 & 0.238 & 0.125 \\
\hline $7-12$ & 0.185 & 0.178 & 0.283 & 0.168 \\
\hline $13-15$ & 0.090 & 0.087 & 0.140 & 0.079 \\
\hline $16-59$ & 2.474 & 2.466 & 2.392 & 2.552 \\
\hline $60-69$ & 0.210 & 0.211 & 0.222 & 0.203 \\
\hline $70-79$ & 0.096 & 0.100 & 0.043 & 0.103 \\
\hline $80-89$ & 0.021 & 0.019 & 0.014 & 0.030 \\
\hline 90- & 0.005 & 0.005 & 0.004 & 0.006 \\
\hline Married \% & 84 & 83 & 91 & 79 \\
\hline Of which remarried & 2.43 & 1.88 & 3.77 & 4.29 \\
\hline Currently divorced & 0.38 & 1.88 & 0.72 & 3.24 \\
\hline Education (in year) & 11.8 & 12.3 & 10.3 & 10.5 \\
\hline
\end{tabular}

Source: 2009 CHIP Urban Sample

Authors' calculation 


\section{References}

Appleton, S., Knight, J., Song, L. and Xia, Q. (2002). “Labor retrenchment in China: Determinants and consequences”, China Economic Review 13 (2-3), 252-275

Appleton S., Knight, J., Song, L. and Xia, Q., 2004. “Contrasting Paradigms: Segmentation and Competitiveness in the Formation of the Chinese Labour Market”. Journal of Chinese Economic and Business Studies, 2 (3), 185-206

SIMON APPLETON, LINA SONG and QINGJIE XIA, 2014. Understanding Urban Wage Inequality in China 1988-2008: Evidence from Quantile Analysis”. World Development 62, $1-13$

Appleton, S and Song, L. (2015). Informality in the Chinese labour market: determinants of entry and pathways to exit (Mimeo)

Blanchflower, David G., and Andrew J. Oswald (1998). "What makes an entrepreneur?" Journal of labor Economics, 16 (1) 26-60.

People's Republic of China: The Bureau of Statistics of PR China (various years) Chinese Statistic Yearbooks

Cai, Fang (2007), “Chinese labour market development and changes in employment”, Economic Research (经济研究), 2007 (7) (in Chinese).

Chen, Liangyu (1999), "Informal labour employment is a cradle for new economic organisations” in Shanghai Social Security, 24 (in Chinese)

De Soto (2002). The other path: an economic answer to terrorism. New York: Basic books

Ding, J., Leng, X., Song, X., Hanner, B., and Xu, Y. (2001), “Conceptualising informality in China: transplant and evolution”. China Population Science, 6 (8) (in Chinese)

Gravois, John (2005). “The De Soto Delusion” Slate, 29 Jan 2005

Giles, J., Park, A., Cai, F., and Du, Y. (2012) Weathering a storm: Survey-based perspectives on employment in China in the aftermath of the global financial crisis, World Bank, Policy Research paper 5984

Harris, John R. \& Todaro, Michael P. (1970), "Migration, Unemployment and Development: A Two-Sector Analysis". American Economic Review, 60 (1): 126-142.

Huang, Philip C. C. (黄宗智) (2013). “China’ s Informal Economy Revisited” (中国的非 正规经济再论), Rural China, 10 (1), 66 -82, Koninklijke Brill NV, Leiden, The Netherlands

Hussmanns, R. (2004). "Measuring the informal economy: From employment in the informal sector to informal employment." Integration Working Paper 53 (2004). 
International Labour Organisation (ILO) (1993). Resolutions Concerning Statistics of Employment in the Informal Sector Adopted by the 15th International Conference of Labour Statisticians, ILO, Geneva.

International Labour Organisation (ILO) (2016), http://www.ilo.org/global/topics/employmentpromotion/informal-economy/lang--en/index.htm

Knight, J. and Song, L. (1999). The rural and urban divide: economic disparities and Interactions in China, Oxford University Press, Oxford

Knight, J. and Song, L., 2003. “Chinese Peasant Choices: Migration, Rural Industry or Farming”, Oxford Development Studies, 31(2), 123-148

Lewis, W. Arthur (1954). "Economic Development with Unlimited Supplies of Labor". The Manchester School 22: 139-91. doi:10.1111/j.1467-9957.1954.tb00021.x.

Laing, Z. (2015). University of Nottingham, PhD thesis (draft)

Li, S. and Knight, J. (2006). "Three Poverties in Urban China," Review of Development Economics, 10 (3), 367-387, 08

Lu, Tu (2013). China’s new workers: lost or arising. PR China: Legal Publishing House

Mohapatra, S., Rozzelle, S., and Goodhue, R. (2007). The Rise of Self-Employment in Rural China: Development or Distress? World Development, 35 (1) 163-181

Song, L. (2000). "Diversification of Household Production in Rural China: Determinants and Outcomes”. In West and Zhao: Rural Labor Flows in China, University of California Press, Berkeley, CA, USA. 101-128

Song, L. and Appleton, S. (2008). "Social protection and migration in China: what can protect migrants from economic uncertainty?” In: NIELSEN, I. and SMYTH, R., eds., Migration and social protection in China, World Scientific.

State Council of PR China (1995): The Labour Law (Dossier 174).

QINNJIE XIA, LINA SONG, SHI LI and SIMON APPLETON, 2014. The effect of the state sector on wage inequality in urban China: 1988-2007 Journal of Chinese Economic and Business Studies. 12(1), 29-45

Zhang, JW and Cai, YF (2012). "Population Changes, Economic Growth and the trend of the labour market”. China Net 2012 12-24 